\title{
A postulação do ser e a recusa do poder ilimitado do discurso na primeira parte do Górgias de Platão
}

\author{
Janaína Silveira Mafra \\ Universidade Federal de Minas Gerais \\ janainamafra@yahoo.com.br
}

\section{RÉSUMÉ}

À partir du Gorgias de Platon, nous montrons que l'objet de la réfutation socratique est le discours, soit-il le produit des croyances de l'interlocuteur ou non, mais que le but de Socrate est principalement de conduire l'énonciateur refuté à se disposer effectivement à connaître quelque chose et à parler ou agir selon les déterminations de cette nouvelle connaissance.

MOTS-CLÉS: élenkhos; réfutation; discours; connaissance; réalisation.

Que tipo de homem eu sou? Daqueles que seriam prazerosamente

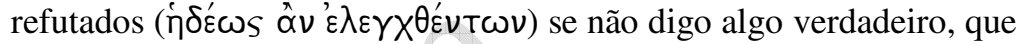

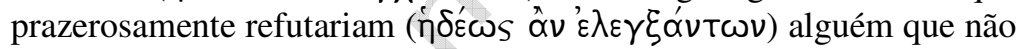
dissesse algo verdadeiro e que certamente não seriam refutados com

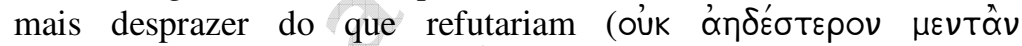
$\left.{ }^{\prime} \varepsilon \lambda \varepsilon \gamma X \theta^{\prime} \varepsilon v \tau \omega \nu \hat{\eta}^{\wedge}{ }^{\prime} \lambda \varepsilon \gamma \xi \xi^{\prime} \alpha \tau \tau \omega \nu\right) .{ }^{1}$ Pois considero isto, [ser refutado], um bem maior, na medida em que é um bem maior alguém ser libertado do maior mal do que libertar outrem. ${ }^{2}$

Segundo Kerferd, as sugestões modernas de que Górgias não deveria ser chamado de sofista repousam em um estreitamento arbitrário desse conceito e não têm por base testemunhos antigos. ${ }^{3}$ No Hipias Maior, Górgias de fato é chamado de o

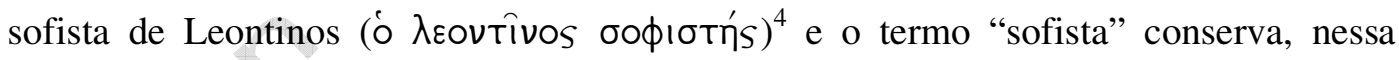
passagem, sua significação original ampla de homem sábio. No Górgias, entretanto,

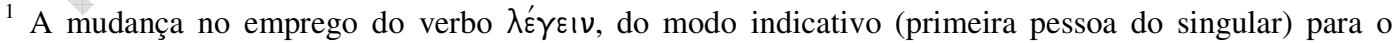

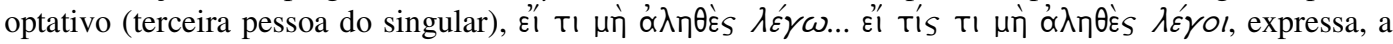
partir de uma construção sintática sutil, que antes de reconhecer a possibilidade de alguém não ter dito algo verdadeiro, Sócrates admite a possibilidade menos remota de ele próprio não tê-lo feito e de ser refutado em função disso. A esse respeito, cf. dica de Dodds, E. R., comentário de Plato. Gorgias. Oxford: Claredon Press, 1959, p. 214. Lembramos que as citações das obras modernas e clássicas vêm todas com traduções nossas. Optamos por manter a maioria dos termos gregos tal como aparecem em seus contextos de ocorrência, conservando o caso, o número, a pessoa, o tempo, etc., a fim de facilitar sua localização. Para as citações de Platão, utilizamos a seguinte edição dos textos gregos: Plato. Platonis Opera. Burnet, J. (org.). Oxford: Clarendon Press, 1900-1907.

${ }^{2}$ Cf. Górgias 458a2-7.

${ }^{3}$ Cf. Kerferd, G. B. O movimento sofista. Tradução de Margarida Oliva. São Paulo: Loyola, p. 80.

${ }^{4}$ Cf. Hipias Maior $282 \mathrm{~b} 5$.
} 
Platão o considera um orador profissional e mestre de retórica; ${ }^{5}$ além disso, estabelece uma distinção precisa entre a sofística e a retórica - enquanto a primeira é caracterizada como usurpadora da imagem da legislação, a segunda é caracterizada como usurpadora da imagem da justiça —, ainda que, como partes da lisonja, ambas se

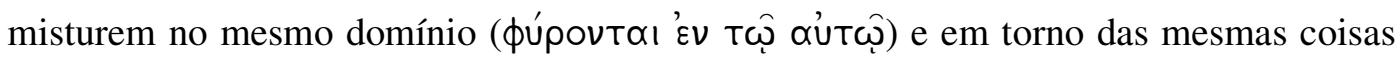
( $\pi \varepsilon \rho i$ т $\alpha \hat{T} \alpha){ }^{6}$

Afinal, o que Górgias é? Sócrates, na primeira parte do diálogo, pede a Querefonte que pergunte a Górgias exatamente isto: öбtıs 'єotí; Antes de mais nada, vale ressaltar que as considerações acerca de Górgias feitas aqui restringem-se à adequação crítica que Platão faz de sua figura ao terreno argumentativo do diálogo. Platão produz um personagem que serve a seus próprios propósitos, e, nesse sentido, esse personagem é uma produção sua; tal produção, no entanto, não é arbitrária, visto que resulta da estratégia de refutação suscitada por problemas implícitos à prática político-pedagógica e aos pensamentos do próprio Górgias, ainda que eles não tenham sido formulados do mesmo modo como em Platão. ${ }^{8}$ No Elogio a Helena, além de elogiar uma mulher, Górgias discorre sobre a habilidade de persuadir, que consiste em

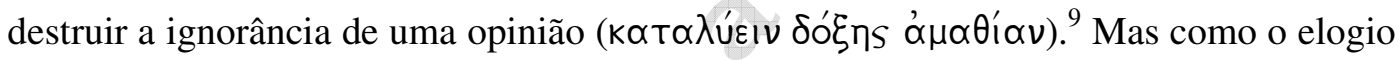
é capaz de destruir a ignorância de uma opinião, se o que ele visa é moldar a alma do ouvinte lançando mão de uma habilidade que, na realidade, não busca ultrapassar a esfera da dóxa? A despreocupação do retor com as conseqüências éticas de uma utilização ilimitada do discurso, compreendido em sua ambivalência como um

\footnotetext{
${ }^{5}$ De acordo com Maria Cecília de Miranda N. Coelho, consideramos questionável a associação restritiva da figura histórica de Górgias à de um orador profissional e mestre de retórica, uma vez que ela pode ser associada à de um investigador dos critérios da verdade e, por conseguinte, à de um filósofo. Cf. introdução à sua tradução de Górgias. Tratado do não-ente. Elogio de Helena. Cadernos de Tradução USP. São Paulo, vol. 4, p. 9-10, 1999. Por outro lado, discordamos de sua afirmação de que o termo ค́пторıкń não ocorre antes de Platão, tampouco a prática desse ofício. Ora, ainda que o termo não fosse encontrado uma única vez em textos anteriores aos de Platão, isso não seria uma prova cabal de que o ofício da retórica não teria sido praticado até então, pois uma coisa pode ter sido praticada mesmo antes de ter sido nomeada. Ademais, não devemos negligenciar a possibilidade de o termo em questão ter ocorrido em textos que se perderam e, por essa razão, não chegaram até nós. Sustentamos, portanto, que, mesmo que conceba no Górgias um personagem ideal, identificado com a figura de um orador profissional e mestre de retórica, Platão não o cria do nada, mas o produz a partir de motivações reais, que, de algum modo, podem ser deduzidas a partir da leitura de seus diálogos.

${ }^{6} \mathrm{Cf}$. Górgias $465 \mathrm{c}$.

${ }^{7}$ Cf. Górgias $447 \mathrm{~d} 1$.

8 A respeito da apropriação que Platão faz do pensamento do sofista Protágoras em seus diálogos Protágoras, Teeteto e Sofista, cf. Marques, M. P. O Sofista: uma fabricação platônica? Kritérion. Belo Horizonte, v. 102, p. 66-88, 2002, e, do mesmo autor, Platão, pensador da diferença. Uma leitura do "Sofista”. Belo Horizonte: UFMG, 2006, p. 116.

${ }^{9}$ Cf. Elogio a Helena \$21.
} 


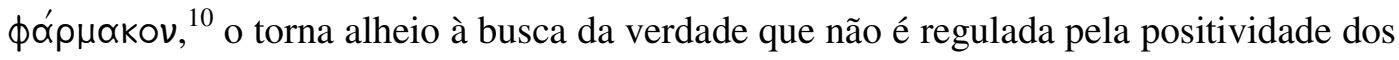
discursos, ${ }^{11}$ ou ainda, à busca da realidade que não se deixa determinar pelas crenças, opiniões e desejos irrefletidos. É devido ao uso ilimitado que o orador pretende fazer da habilidade discursiva de que dispõe, capaz de modificar a aparência das coisas, que Platão o considera terrível ( $\delta \varepsilon ı$ vós $){ }^{12}$

O objetivo deste artigo, que não se restringe a uma análise histórica do pensamento de Górgias, é explicitar o sentido filosófico da inflexão que Platão realiza não só de sua figura, mas também da de Sócrates, razão pela qual alguns helenistas, como Charles Kahn, ${ }^{13}$ por exemplo, recusam a clássica divisão dos diálogos em socráticos e platônicos. Vlastos, antes dele, ordenando o corpus de modo sistemático e evolutivo, sustenta que os problemas dos ditos diálogos socráticos, também chamados de elênticos, vão pouco a pouco sendo superados pelos ditos diálogos platônicos, também chamados de metafísicos. O período de transição seria o marco da ruptura com o pensamento socrático, uma vez que compreenderia o Mênon, no qual Platão desenvolveria, pela primeira vez, o próprio sistema metafísico da teoria da

${ }^{10} \mathrm{Na}$ medida em que pode ser utilizado não só como uma persuasão boa, mas também como uma persuasão má, o discurso tem para Górgias um caráter ambivalente: a relação entre os remédios e os corpos é semelhante a que existe entre os discursos e as almas, pois assim como os homens retiram das drogas alguns humores do corpo, uns que cessam a doença, outros a vida; outros retiram dos discursos alguns humores da alma, uns que atormentam, agradam, aterrorizam ou levam os ouvintes a uma situação de confiança e outros que drogam e enfeitiçam a alma por meio de uma persuasão má. Cf. Elogio a Helena $\$ 14$

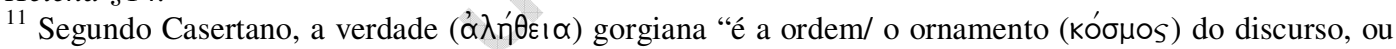
seja, é aquilo que resulta da disposição das palavras numa expressão cuidada"; compreendida desse modo ela não é uma qualidade em si, mas uma construção inerente ao lógos. O problema político da relação dessa verdade com a regulação do discurso, no entanto, é deixado em aberto: quem, como e quando pode e deve exercê-lo? Cf. Casertano, G. Palavra, verdade e engano em Górgias de Leontinos. Cadernos de Filosofia. Lisboa, vol. 9-10, p. 113-132, 2001. Parece ser essa uma lacuna do pensamento do próprio Górgias.

${ }^{12}$ Cf. Banquete 198c. Associando a figura do retor à de um monstro terrível, Sócrates teme que contra seu discurso Agatão lhe envie a cabeça de Górgias, orador temível, e o transforme numa pedra sem voz. Na Odisséia XI 634, é dito: "Um medo esverdeante me toma, não me envie do Hades a augusta Perséfone a

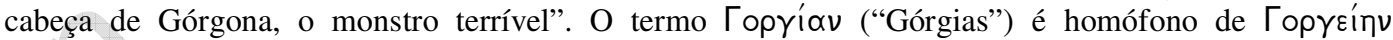
("Górgona"). Sobre o trocadilho, cf. Brisson, L. introdução, tradução e notas de Platon. Banquete. Paris: GF-Flammarion, 1998, p. 206 (nota 343); sobre o mito de Górgona, cf. Quesnel, A. A Grécia. Mitos e lendas. Tradução de Ana Maria Machado. São Paulo: Editora Ática, 1996.

${ }^{13}$ Embora reconheça que o fato de Platão ter recebido influências diretas do Sócrates histórico não torna menos platônica a elaboração de suas idéias, Kahn não parece romper totalmente com o caráter sistemático e evolutivo da clássica ordenação do corpus, pois considera os ditos diálogos socráticos como expressões parciais do que será exprimido de modo mais completo apenas no período intermediário. Segundo sua cronologia, o Górgias faria parte do grupo de diálogos que antecederia o do Mênon, que introduziria os temas abordados nos diálogos intermediários: 1. Diálogos de juventude ou "présistemáticos": Apologia (após 399), Criton, Íon, Hípias Maior, Górgias (390-386) e Menexeno (386-385); 2. Pré-intermediários ou "socráticos": Láques, Cármides, Lísis, Eutífron, Protágoras, Eutidemo e Mênon; 3. Intermediários (a doutrina das formas): Sympósium (após 385, antes 378), Fédon, Crátilo, República e Fedro; 4. Pós-intermediário: Parmênides e Teeteto (logo após 369). Cf. Kahn, C. H. Did Plato write socratic dialogues? Classical Quarterly. Oxford, vol. 31, p. 306-309 e 320, 1981. 
reminiscência, que superaria as limitações epistemológicas dos chamados diálogos elênticos. ${ }^{14}$ Consideramos, contudo, que essa interpretação não pode ser justificada, pois Platão jamais abandona a prática filosófica do élenkhos, ao invés disso, não cansa de situá-la — seja nos primeiros diálogos, seja nos posteriores ${ }^{15}$ — no horizonte interrogativo do diálogo, cujo fim, que nem sempre é alcançado, é a ultrapassagem das opiniões, ou ainda, o conhecimento do que é.

Após essa pequena digressão, ensejo para a explicitação de nossa posição

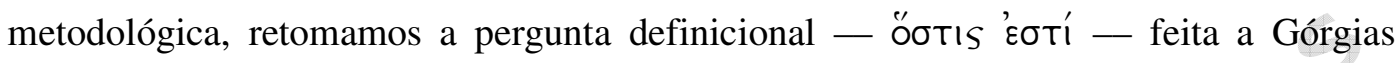
depois de sua exibição oratória $\left(\ell^{\prime} \pi^{\prime}{ }^{\prime} \delta \varepsilon \mid \xi ı\right) .{ }^{16}$ É o impetuoso Polo, porém, que responde em seu lugar; sem conversar de modo reto (o $\rho \theta \omega s),{ }^{17}$ ele diz que Górgias figura entre os melhores e participa das artes mais belas. ${ }^{18}$ Nesse momento do diálogo, Platão contrapõe a conversa filosófica $(\delta ı \alpha \lambda \varepsilon ́ \gamma \varepsilon \sigma \theta \alpha ı)$, que é determinada pelo objeto do

14 Segundo Vlastos, o "problema do élenkhos", que consistiria em saber como deduzir conclusões verdadeiras a partir da refutação de premissas doxásticas, só poderia ser superado a partir da consideração do sistema metafísico das teorias da reminiscência e da imortalidade da alma desenvolvidas por Platão a partir do Mênon. Sua posição, que nos parece equivocada, visto que supervaloriza as crenças e se baseia numa compreensão sistemática e evolutiva do corpus, é a de que a verdade buscada existiria de modo tácito na alma do interlocutor sob a forma de crenças verdadeiras, pois a alma, sendo imortal, teria contemplado as realidades perfeitas: as crenças verdadeiras resultariam nas proposições a partir das quais a negação das teses errôneas seria deduzida. Cf. Vlastos, G. The socratic elenchus: method is all. In: . Socratic studies. Cambridge: University Press, 1994, p. 29-30.

${ }^{15}$ Cf., por exemplo, Sofista 259a, onde o Estrangeiro considera a possibilidade de ter seu discurso refutado $\left({ }^{\prime} \lambda^{\prime} \varepsilon \dot{\gamma} \xi \alpha_{S}\right)$, desde que seus pretensos refutadores se disponham antes a percorrer o mesmo caminho investigativo que o seu, a partir do qual foi estabelecida uma forma do não-ser, que não é o contrário do ser, visto que dele participa.

${ }^{16} \mathrm{~A} \varepsilon^{\prime} \pi_{1}^{\prime} \delta \varepsilon|\xi| s$ é uma prática discursiva bastante utilizada pelo orador, que pretende mostrar publicamente não só sua habilidade de responder a qualquer pergunta, mas também sua sabedoria. Cf. Liddell, H.; Scott, R.; Jones, S. A Greek-English lexicon. Oxford: Clarendon Press, 1996, p. 629; cf. também Górgias 447c e Mênon 70c.

${ }^{17}$ Traduzimos o $\rho \theta \omega \hat{s}$ por "retamente", termo que conserva os sentidos geométrico, ético e estilístico do correspondente grego: com retidão (sem sinuosidade), com justiça/ franqueza e com simplicidade, ver Chantraine, P. Dictionnaire étymologique de la langue grecque. Paris: Klincksieck, 1977, p. 818-819. Segundo o levantamento de ocorrências, realizado a partir do Thesaurus Linguae Graeca, é manifesta a preocupação de Platão com a retidão do pensamento, do discurso e da ação.' O $\rho \theta \omega \hat{s}$ ocorre apenas uma vez no Elogio a Helena e nenhuma no Tratado do não-ser e na Defesa de Palamedes, ao passo que aparece trinta e uma vezes no Górgias de Platão, na maioria delas determinando um modo de dizer.

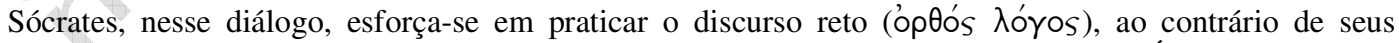
interlocutores, que, apesar de fazerem inúmeras referências a ele, não o praticam. É o modo reto de raciocinar que distingue o discurso filosófico, que é determinado pelo objeto do conhecimento, do retórico, que se furta de modo sinuoso a qualquer tipo de determinação.

${ }^{18}$ Perdendo de vista a pergunta que lhe é feita, Polo expõe sua tese de que a descoberta das TÉ Xvœı se dá a partir da ' $\varepsilon \mu \pi \varepsilon ı \rho^{\prime} \alpha$ : "Há muitas artes descobertas de modo habitual a partir dos procedimentos habituais,

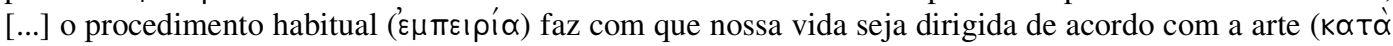

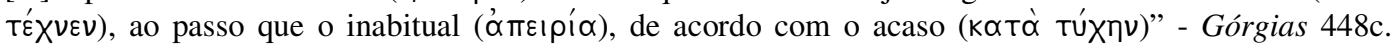
Discordamos daqueles que se valem dessa passagem como uma base sólida para a reconstrução das posições "empiristas" do Polo histórico, pois o contexto a partir do qual ela é extraída, embora aluda ao

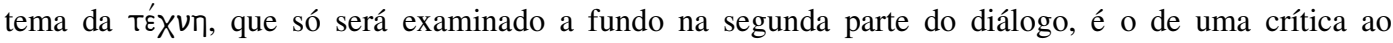
discurso evasivo do jovem Polo, que não responde precisamente às perguntas que lhe são feitas. Dodds considera que, nessa passagem, Platão faz uma caricatura de Polo, cuja pretensão ao poder é ilimitada; cf. Dodds, op. cit., 1959, p. 9. 
conhecimento, à retórica ( $\rho$ пторıкń), caracterizada pelo modo evasivo de conversar daqueles que se recusam a responder de modo preciso às perguntas que lhes são feitas: ${ }^{19}$

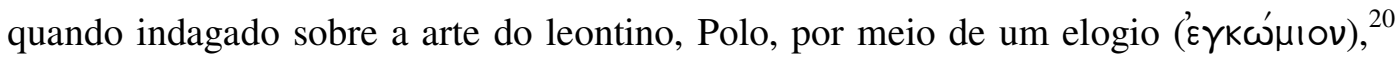
diz uma qualidade ( тоí́ TIS) dela, mas não responde como Górgias deve ser chamado, tampouco o que ele é. ${ }^{21}$ Em sentido amplo, $\delta ı \alpha \lambda \varepsilon ́ \gamma \varepsilon \sigma \theta \alpha ı$ significa "conversar", "falar com”. Platão, todavia, dá ao verbo outro sentido, pois o compreende como um modo investigativo de conversar, um modo elêntico, que, pondo em questão a maneira doxástica de discutir, pretende ir além dela. Conversar filosoficamente é submeter-se à

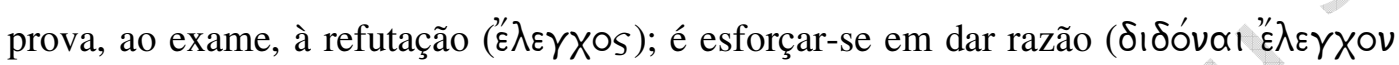
ou $\lambda$ ó $\gamma$ ov) do discurso proferido e, se for o caso, da maneira que se vive. ${ }^{22}$ Platão resignifica a prática do discurso ao situá-la no horizonte filosófico da indagação inteligente, ou seja, da pergunta posta em função de uma necessidade inerente à busca do que é ${ }^{23}$ pergunta que ora demanda a tentativa de sua reformulação, ora a tentativa da formulação de uma reposta precisa. Chantraine traduz o verbo $\delta ı \propto \lambda \varepsilon^{\prime} \gamma \circ \mu \propto \iota$, forma composta derivada a partir do verbo $\lambda^{\prime} \varepsilon \varepsilon \varepsilon ı$, tanto por sua significação ampla de “conversar" e "dialogar", como por sua significação estrita de "pôr em prática a dialética" ${ }^{24}$ Não devemos, contudo, confundir a prática filosófica do $\delta ı \alpha \lambda \varepsilon ́ \gamma \varepsilon \sigma \theta \propto ı$ com o resultado da paidéia ou coroamento das ciências referido na República: a dialética ( $\delta ı \propto \lambda \varepsilon \kappa T I K \eta ́)$. Enquanto a forma verbal designa uma maneira de conhecer ou pensar mediante a troca de perguntas e respostas, a forma nominal, ao menos em seu sentido técnico, designa a última etapa do percurso educativo: "[...] Como um coroamento das ciências, a dialética se situa para nós lá no alto". ${ }^{25}$

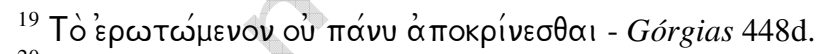

${ }^{20}$ No Elogio a Helena, Górgias faz um encômio a essa mulher, objeto de censura por grande parte dos homens. Na Defesa de Palamedes, de modo semelhante, Górgias justifica, em nome de Palamedes, a apologia que faz de sua vida passada: "Se não fosse acusado, seria inconveniente dizer essas coisas, mas sou acusado, portanto, convém dizê-las" - §28. No Górgias, Sócrates critica a disposição oratória de Polo de elogiar ou defender algo - sem se comprometer com a busca de sua definição — como se alguém o atacasse ou censurasse: "Elogias a arte dele como se alguém a censurasse, mas não respondes o que ela é/

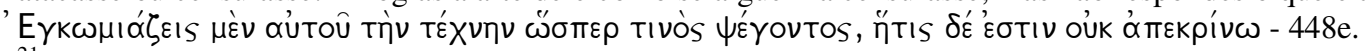

${ }^{21}$ Cf. Górgias 448e-449a. A pergunta "como Górgias deve ser chamado?" remonta a esta outra, "o que Górgias é?", que remonta a esta outra, "o que Górgias conhece?", que, por sua vez, remonta a esta outra, ainda mais "objetiva", "qual é o objeto do pretenso conhecimento técnico de Górgias?". O objeto do conhecimento de um homem é compreendido aqui como o princípio de determinação de seu poder.

${ }^{22}$ Cf. Láques 187e-188a e Apologia 38a.

${ }^{23}$ Lembramos que o termo $\delta ı \alpha \lambda \varepsilon ́ \gamma \varepsilon \mid \nu$ significa distinguir, separar; sentidos que se confundem com os de ó $\zeta_{\zeta}$ ¿ıv: separar, delimitar, cercar, definir; Cf. Liddell; Scott; Jones, op. cit., 1996, p. 400 e 1250.

${ }^{24}$ Cf. Chantraine, op. cit., p. 625.

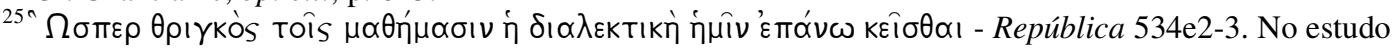
que realiza sobre os livros VI-VII da República, Dixsaut chama a atenção para o fato de que aquilo a que freqüentemente chamamos de dialética, que consistiria na atividade do conhecimento, isto é, na 
Outro aspecto da conversa filosófica é a ironia. Quando passa a fazer perguntas no lugar de Querefonte, Sócrates diz de modo irônico que Polo parece ter sido preparado para os discursos ${ }^{26}$ e se esquiva dele, passando, então, a questionar o próprio Górgias. $^{27}$ A ironia não deve ser compreendida nesse contexto como uma dissimulação, ${ }^{28}$ mas como uma estratégia de enunciação que não fornece o sentido completo das palavras empregadas; uma estratégia discursiva que instiga o interlocutor a refletir acerca do sentido que não é dado. Sócrates se esquiva de Polo não apenas por

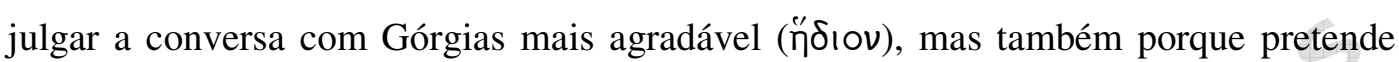
fazer com que o jovem retor pare temporariamente de falar e faça um exame das próprias palavras, a fim de que reflita sobre o modo retórico como as conduziu. A ironia desempenha, portanto, um papel importante na prática do élenkhos socrático: levar o interlocutor a examinar por si mesmo aquilo que ele provavelmente se recusaria a examinar se lhe fosse revelado pelo discurso direto de um outro. ${ }^{29}$ Passando então a ser interrogado por Sócrates, que lhe pergunta como conhecedor de que arte é preciso chamá-lo, ${ }^{30}$ Górgias responde: de retórica (тñs ṕnтopıkñs). Platão aproveita a ocasião para mostrar a vaidade do retor, que, fazendo um elogio a si, gaba-se da própria excelência e capacidade: Górgias se considera um orador bom e capaz de produzir outros oradores. Segundo Dodds, Platão se abstém de fazer uma crítica incisiva a Górgias, que é tratado com o respeito devido à sua idade, probidade e habilidade literária. ${ }^{31}$ De fato, na primeira parte do diálogo, o velho retor é atingido apenas pela via

capacidade de fazer perguntas boas e de respondê-las, é, na verdade, a potência do dialégesthai. Cf. Dixsaut, M. Métamorphoses de la dialetique dans les dialogues de Platon. Paris: Vrin, 2001, p. 70.

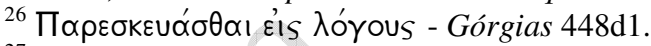

27 As substituições das perguntas de Querefonte pelas de Sócrates e das respostas de Polo pelas de Górgias são um dos indícios de que as perguntas de Querefonte se inspiram no modo socrático de conversar e as respostas de Polo se inspiram na retórica gorgiana. A esse respeito, ver de Souza, J. C. A caracterização dos sofistas nos primeiros diálogos platônicos. Boletim - USP: Língua e Literatura Grega. São Paulo, vol. 8, p. 111, 1969.

${ }^{28}$ Dissimulação é a significação pejorativa do termo घ̇ exemplo, República 337a4, quando Trasímaco, em tom de contenda, refere-se à ironia ou dissimulação

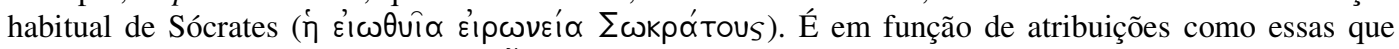
Sócrates jamais se refere como um हli conversas um outro tipo de ironia, a "oracular", que provoca a investigação por não dizer tudo o que pretende. Devemos a Fernando Muniz a noção de "ironia oracular", bem como a compreensão do papel de sua articulação com o élenkhos socrático. Cf. Muniz, F. Dialética socrática entre a ironia e a parrhesia. Boletim do CPA. Campinas, vol. 13/14, p. 97-108, 2002.

${ }^{29}$ Embora o papel desse tipo de ironia seja levar o interlocutor a fazer ele próprio um exame de seus discursos e atos, esse auto-exame pode não acontecer, primeiro porque quem faz uso da ironia não

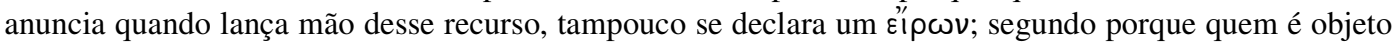
da ironia pode, por um temor do desconhecido, recusar-se a pôr à prova as próprias crenças e opiniões.

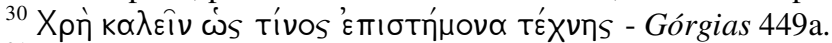

${ }^{31}$ Cf. Dodds, op. cit., p. 9. 
indireta do exame que Sócrates faz de seu discurso, ${ }^{32}$ mas suas enunciações são construídas de modo acintoso com tanta pompa e sofisticação, que o leitor passa a lhe atribuir, não sem razão, qualidades como afetação $^{33}$ e imodéstia. ${ }^{34}$ Ademais, não devemos negligenciar que os discursos de Polo e Cálicles, refutados ao longo do diálogo, nada mais são do que a explicitação dos pressupostos subjacentes não só às posições, mas também às práticas político-pedagógicas de Górgias.

Com o assentimento dos interlocutores, Sócrates estabelece, na seqüência, as condições para o desenvolvimento da conversa elêntica. Esta deve ser realizada paulatinamente $\left(\mathrm{K} \propto \mathrm{T} \alpha \dot{\beta} \beta \rho \alpha \chi \chi^{\prime}\right),{ }^{35}$ mediante a troca de perguntas e respostas (Tò $\mu \dot{\varepsilon} \nu$

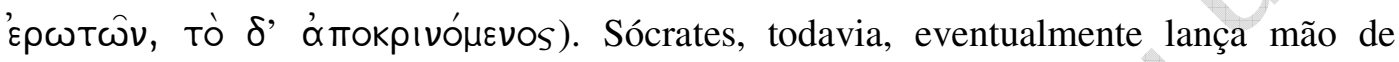

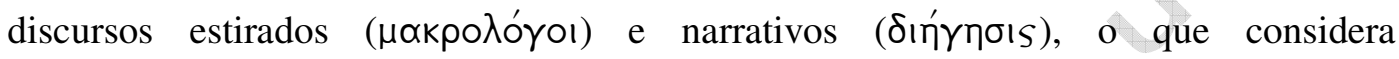

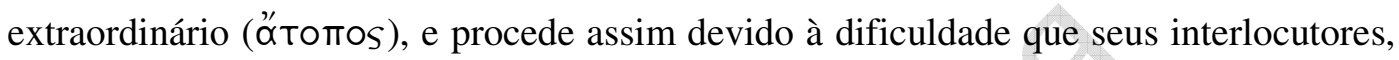
como Polo, por exemplo, têm em compreender suas enunciações mais concisas e diretas. Vale ressaltar que, embora prefira discursos breves, Sócrates não considera a concisão ( $\beta \rho \propto \chi \cup \lambda o \gamma i ́ \alpha)$ um critério suficiente para a formulação de respostas retas e precisas. Górgias é um exemplo disso, pois mesmo gabando-se da própria concisão, enuncia discursos tão genéricos que não responde de modo preciso às perguntas que lhe são feitas. Portanto, o que Sócrates espera não é tanto que o interlocutor enuncie discursos breves, mas que ele participe da conversa filosófica, isto é, do diálogo estabelecido pouco a pouco por meio da troca de perguntas e respostas, o único capaz de interromper o fluxo contínuo do discurso daqueles que, de uma só vez, acreditam ter tornado inteligível para si e para os outros a realidade. Não é a extensão do discurso que caracteriza a conversa filosófica, mas o modo de pensar daqueles que não temem a

\footnotetext{
${ }^{32}$ Sócrates diz que interroga Górgias não por causa dele: "Não por causa de ti, mas do lógos, a fim de que

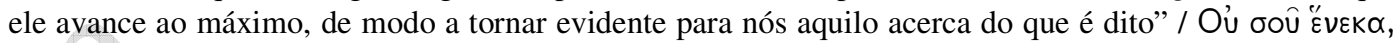

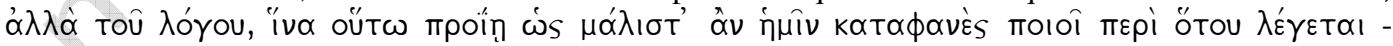
Górgias 453c-d.

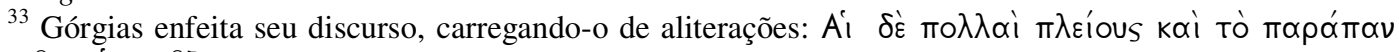
$\pi \hat{\alpha} \sigma \alpha \hat{\eta} \pi \rho \hat{\alpha} \xi 1 s . .$. (450d) e de termos raros e rebuscados. No Mênon, o estilo Gorgiano é caracterizado como trágico, espetacular, grandiloqüente. Sócrates diz a Mênon, quando este responde à maneira de

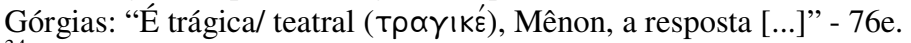

${ }^{34}$ Gabando-se de sua habilidade discursiva e saber, Górgias diz: "Afirmo que há muitos anos ninguém, de

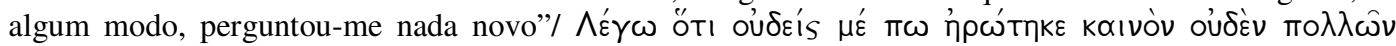

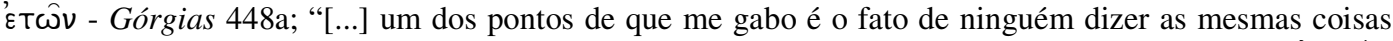

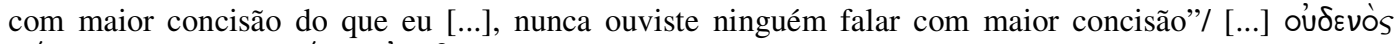

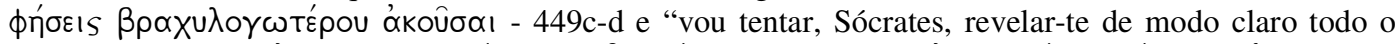

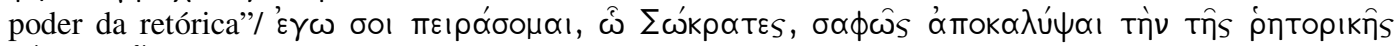

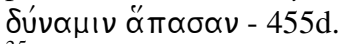

${ }^{35}$ Pouco a pouco, conforme Liddell; Scott; Jones, op. cit., p. 329.
} 
refutação e o impasse; daqueles que se lançam com paciência e tenacidade no horizonte imprevisível da pergunta: o que é?

A conversa entre Sócrates e Górgias começa como a que acontece entre Sócrates e Nícias, no Láques, onde uma pergunta definicional é feita e uma resposta é formulada e examinada, dando origem a uma série de perguntas que exigem respostas cada vez mais precisas. Sócrates pergunta a Górgias: a retórica é o conhecimento acerca de qual

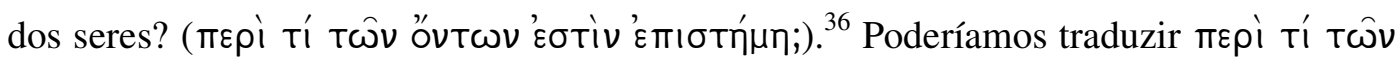

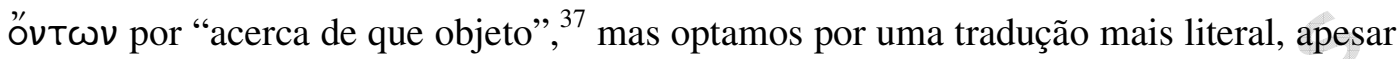
de pouco eufônica: "acerca de qual dos seres", a fim de destacar que o núcleo indeterminado do sintagma, o Tí, indica um dentre os muitos seres ou coisas existentes, expressos pelo sintagma em genitivo plural, $\tau \hat{\omega} \nu$ óv $\tau \omega \nu .{ }^{38} \mathrm{Em}$ termos filosóficos, isso significa que, embora haja diversos seres, aquele que deve ser apontado como o objeto do conhecimento da arte retórica ainda não foi apanhado; apanhá-lo é diferenciar a retórica das outras artes, ou seja, é apontar sua especificidade, ou ainda, restringir seu

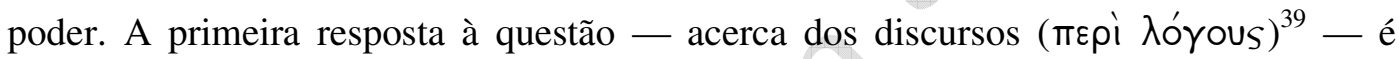
imprecisa, pois pode ser aplicada a todas as T'́x $\chi \propto \alpha ı$, uma vez que "cada arte se refere ao discurso respectivo a seu objeto". ${ }^{40}$ Sócrates chama a atenção de seu interlocutor para o fato de que os lógoi não devem ser situados entre os objetos, pois há, de um lado, o

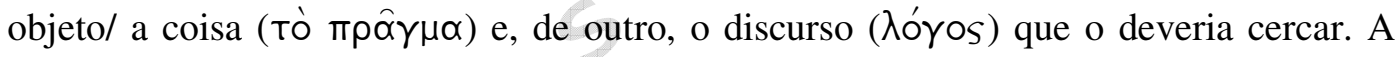
finalidade de Platão aqui é fazer ver, a partir de uma construção argumentativa sutil, que levar o retor a apanhar pelo discurso o objeto de sua pretensa arte é o mesmo que leválo a admitir as determinações de seu lógos e, portanto, do poder de sua prática profissional.

Esquivando-se da objeção feita por Sócrates, Górgias tenta definir sua suposta arte apontando o instrumento de sua prática. Ele diz que há artes cujo conhecimento se relaciona com atividades manuais ou práticas afins, mas que a retórica não se relaciona com esse tipo de atividade, visto que sua prática e autoridade são alcançadas "por meio" dos discursos $\left(\delta ı \grave{\alpha} \lambda o_{\gamma} \omega v\right) .{ }^{41}$ A segunda definição de Górgias também é imprecisa, pois

\footnotetext{
${ }^{36}$ Cf. Górgias 449d.

${ }^{37}$ Cf., por exemplo, traduções de M. Canto-Sperber (Platon. Gorgias. Paris: GF-Flammarion, 1989) e A. Croiset (Platon. Gorgias. Paris: Les Belles Lettres, 1949). Dodds não comenta essa passagem.

${ }^{38}$ Para aspectos da língua, ver a gramática de grego antigo de Crespo, E.; Conti, L; Maquieira, H. Sintaxis del Griego Clássico. Madrid: Gredos, 2003, p. 129.

${ }^{39}$ Cf. Górgias 449e1.

${ }^{40}$ Cf. Górgias 450a-b.

${ }^{41}$ Cf. Górgias $450 \mathrm{~b} 9$.
} 
a retórica não é a única arte que utiliza o discurso ${ }^{42}$ como seu instrumento: a aritmética, o cálculo, a geometria e muitas outras artes são realizadas inteiramente por meio do

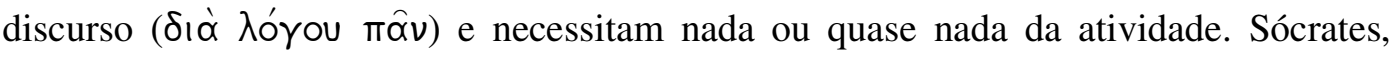
então, pergunta novamente a Górgias: acerca de qual dos seres são os discursos que a retórica utiliza ${ }^{43}$ Retrocedendo ao modo evasivo de responder de Polo, que, em 448e449a, qualifica o objeto da definição antes mesmo de tê-lo definido de maneira satisfatória, Górgias responde que os discursos utilizados pela retórica são acerca das coisas humanas, as melhores ( $\alpha$ pı $\sigma \tau \alpha)$ e as mais importantes ( $\left.\mu \varepsilon^{\prime} \gamma ı \tau \alpha\right)$. Sócrates, em seguida, faz alusão a uma canção popular ${ }^{44}$ a fim de mostrar que não há acordo sobre quais são as coisas humanas melhores e mais importantes, pois cada profissional considera melhor o bem produzido por sua arte: o médico considera a saúde; o pedótriba, a beleza e o homem de negócios, a riqueza.

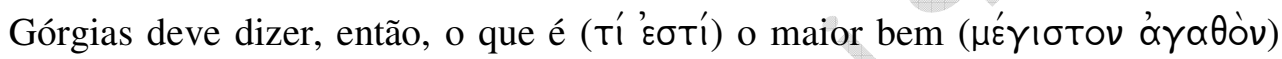

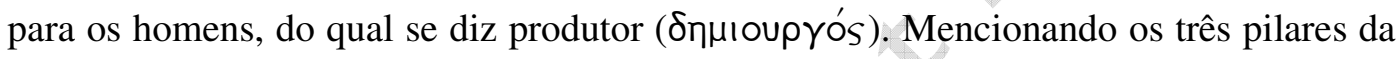
democracia ateniense, ele afirma que o maior bem para os homens é o fato de, por meio dos discursos, eles se tornarem capazes de persuadir juízes no tribunal, conselheiros no conselho e cidadãos na assembléia. Embora cada uma dessas instâncias seja responsável por funções específicas, as três compreendem a reunião política (moגıтıkòs

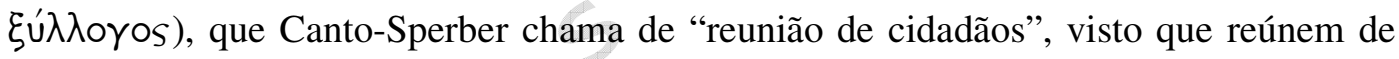
cinquienta a seis mil cidadãos. ${ }^{45}$ Górgias apresenta a persuasão em seu âmbito prático das reuniões políticas de um modo geral, nas quais a habilidade do orador decide o

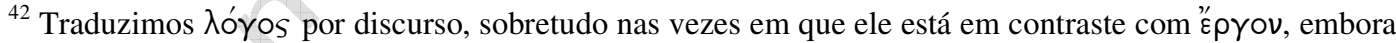
o termo também tenha outras significações: razão, explicação, argumento, raciocínio etc. - Chantraine, $o p$.

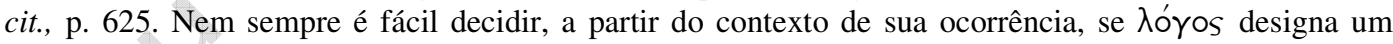
raciocínio não proferido (i.e., um discurso silencioso da alma com ela mesma) ou se um raciocínio proferido. Nos casos em que o contexto conta com essa ambigüidade, empregamos o termo discurso, sem resolvermos se ele é proferido ou não. Vale lembrar que, enquanto no Górgias, o mesmo nome pode ser

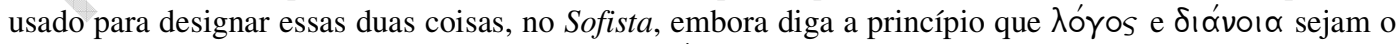

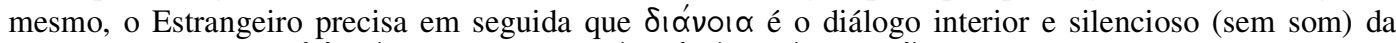
alma com ela mesma/ ó Ev

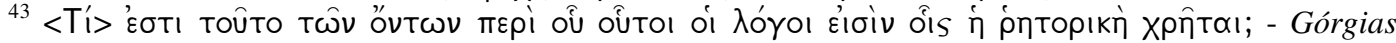
451d.

${ }^{44}$ A canção entoada pelos comensais nos banquetes enumera quatro bens: o melhor (åpıotov) é ter saúde

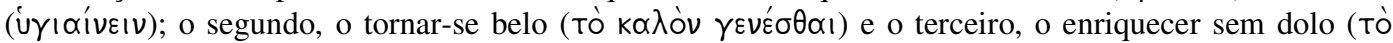

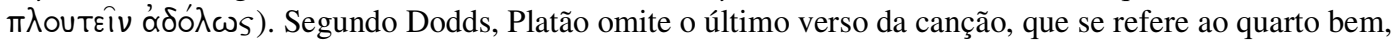

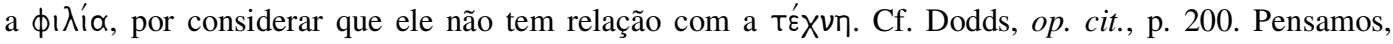
entretanto, que essa omissão pode ser mais um recurso utilizado por Platão, a fim de chamar a atenção para o fato de que é precisamente este bem, a $\phi ı \lambda_{i} \alpha$, que falta aos interlocutores de Sócrates.

${ }^{45}$ Para uma explicação breve, mas esclarecedora, a respeito das três instâncias, ver Canto-Sperber, M. introdução, tradução e notas de Platon. Gorgias. Paris: GF-Flammarion, 1993, p. 316 (nota 15).
} 
rumo de importantes deliberações ${ }^{46}$. A persuasão é considerada por ele o maior bem para os homens porque é a causa (ó'itıov) de torná-los aptos a dominar os outros em suas respectivas cidades; porque é a causa do poder e do domínio, e este, como Tucídides mostra na Oração Fúnebre, é o sustentáculo dos valores de auto-suficiência e liberdade, arraigados em Atenas no século de Péricles. ${ }^{47}$ Sócrates, enfim, reitera a quarta definição dada por seu interlocutor: a retórica é a produtora da persuasão ( $\pi \varepsilon ı \theta 0 u ̂ S$

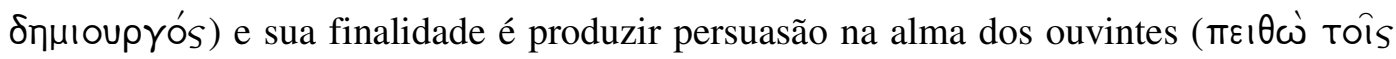

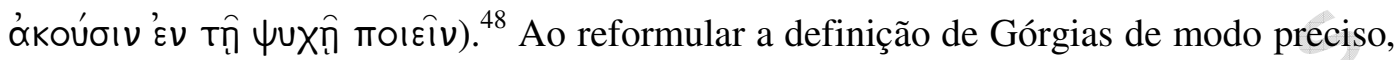
Sócrates mostra que presta atenção em suas palavras; ${ }^{49}$ ele se esforça em apanhar, ${ }^{50}$ a partir do exame delas, aquilo a que elas se referem. Sócrates dialoga com Górgias querendo saber acerca do que é o seu $\log o s,{ }^{51}$ e, ainda que suspeite sabê-lo, continua a interrogá-lo a fim de não antecipar suas palavras fazendo suposições. ${ }^{52}$

A quarta definição de Górgias também é imprecisa, pois há outras artes que produzem persuasão, como, por exemplo, a aritmética, que ao ensinar algo persuade acerca daquilo que ensina. É preciso, então, determinar que tipo de persuasão (roí $\alpha$ S

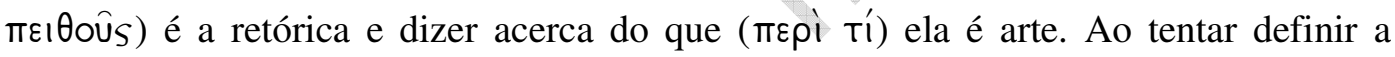
retórica pela quinta vez, Górgias finalmente aponta para um dos objetos centrais da reflexão socrática, a justiça. Ele diz que a retórica produz persuasão nos tribunais e em

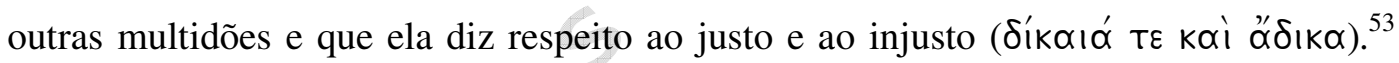
Sócrates presume a resposta de seu interlocutor, mas continua a lhe fazer perguntas, e alega proceder assim não por causa dele, ${ }^{54}$ mas a fim de que o discurso se desenvolva e

\footnotetext{
${ }^{46}$ Hansen lembra que o termo "político" pode ser compreendido simplesmente como uma versão dos

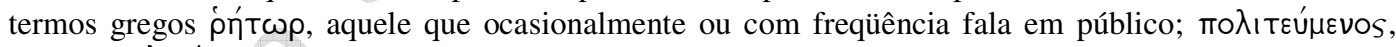
cidadão; oú oú $\mu ß o u \lambda o s$, conselheiro. Em suma, político é todo aquele que faz um uso público da palavra. Cf. Hansen, M. H. The Athenian "Politicians", 403-322 B.C. Greek, Roman and Byzantine Studies. Duke, vol. 24, n. 1, p. 36-37, 1983.

${ }^{47}$ Para a noção corrente de liberdade, compreendida como uma conseqüência do domínio e do poder, cf. discurso de Péricles em Tucídides II, §35-46.

${ }^{48}$ Cf. Górgias 453a.

${ }^{49} \mathrm{O}$ termo бuvı́́vaı é empregado em seu sentido metafórico: prestar atenção, escutar e compreender. Cf. Liddell; Scott; Jones, op. cit., p. 1718. Se Platão tem um grande respeito por Górgias no diálogo, como afirma Dodds, é porque radicaliza e examina suas posições.

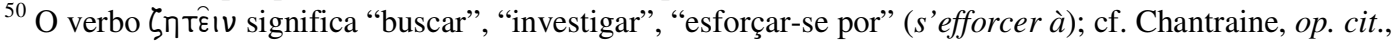
p. 400. O esforço investigativo é a efetivação do desejo de capturar, a partir do que se tem, o discurso, aquilo que se busca e que ainda é falta, o ser.

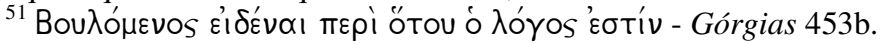

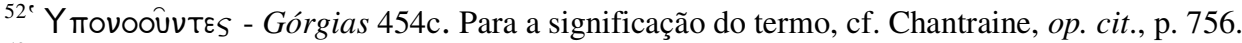

${ }^{53}$ Cf. Górgias 454b.

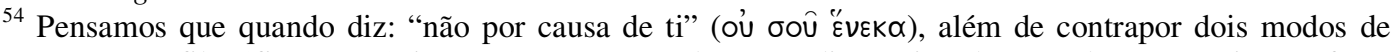
conversar (o filosófico ao erístico), Sócrates pretende persuadir seu interlocutor de que continua a fazer perguntas "não por causa dele", "não em favor dele", "não a fim de libertar sua alma pela refutação",

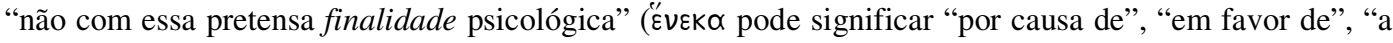


que ambos não adquiram o hábito de antecipar as palavras um do outro, fazendo suposições. Sócrates sabe que as suposições demandam mais investigação, mais exame, pois são tão falíveis quanto às opiniões. Ao continuar fazendo perguntas, ele se predispõe a escutar e a examinar o que Górgias tem a dizer sobre sua suposta arte; essa abertura para o lógos enunciado pelo outro é decisiva, visto que é constitutiva do percurso investigativo. É essencial para o desenvolvimento da pesquisa compartilhada que o interlocutor se esforce não só em dar as razões do que diz, mas também em escutar e examinar as razões dadas pelo outro, ou seja, o interlocutor deve se esforçar não só em dar o lógos, mas também em recebê-lo, e dizemos que ele deve se esforçar porque, como o diálogo mostra, não é fácil dar as razões do que se diz, tampouco acolher com discernimento as razões dadas pelo outro.

Após sustentar que, além da retórica, outras artes produzem persuasão, como a aritmética, que ao ensinar algo persuade acerca daquilo que ensina, Sócrates espera de seu interlocutor que defina sua pretensa arte levando em consideração a diferença que

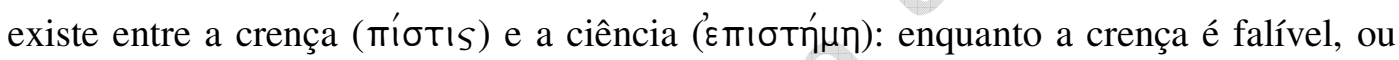

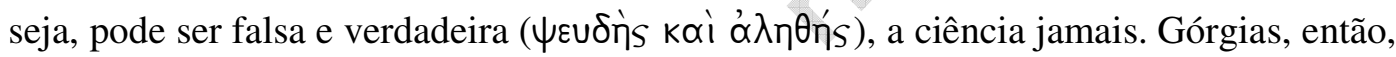
precisa sua definição ao admitir que a retórica produz a persuasão que gera o crer sem o

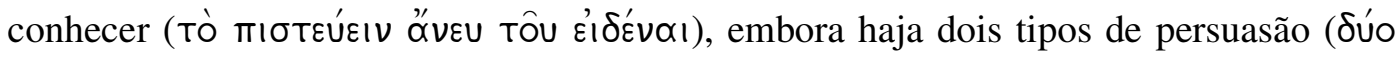

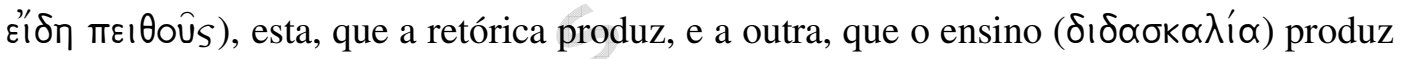

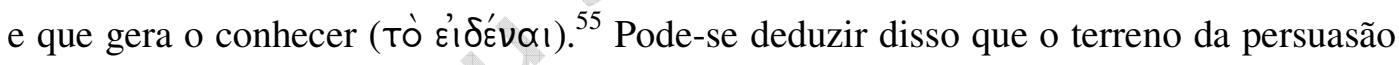
não é restrito à esfera da crença sem conhecimento; ele abarca também a esfera do conhecimento, pois não só o retor persuade quando discorre sobre o que não conhece, mas também o professor, quando ensina o que conhece. Portanto, a relação que existe entre crença e conhecimento não é de oposição, como se imagina, mas de diferença,

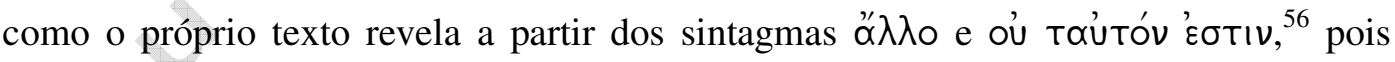
aquele que conhece algo também é levado a crer naquilo que conhece, embora aquele que tem uma crença nem sempre conhece aquilo que aparenta conhecer. É a esta crença,

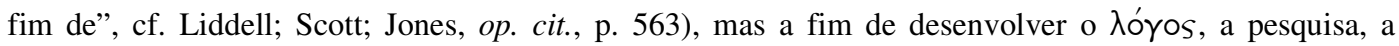
investigação. Percebendo que Górgias teme a refutação, Sócrates tenta persuadi-lo de que não refuta o homem, mas o lógos, dito de outro modo, tenta persuadi-lo de que o exame pode ser enfrentado com menos parcialidade e reserva.

55 No Teeteto, Sócrates diz que os oradores "persuadem não ao ensinar, mas ao produzir opiniões"/

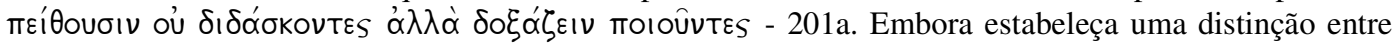
crença/opinião e ciência/conhecimento, Platão não parece estabelecer uma distinção muito precisa entre

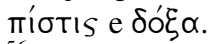

${ }^{56}$ Cf. Górgias 454d. 
apenas, que se faz passar pelo conhecimento, usurpando sua imagem, bem como à pretensa arte que a engendra, que Sócrates se opõe e pretende refutar.

Incomodado com o poder ilimitado da retórica, Sócrates argumenta que o orador não tem o conhecimento necessário para ensinar nos tribunais e demais multidões a respeito do justo e do injusto, tampouco para aconselhar a respeito da escolha de generais, das construções de muralhas, portos e arsenais. Apenas um тєкVIkós, ou seja, um artista ou expert, como o estratego ou o arquiteto, teria o conhecimento necessário para isso. Górgias contesta seu argumento ao lembrar que as fortificações de Atenas foram construídas não em função dos conselhos dos arquitetos, mas da decisão e dos conselhos

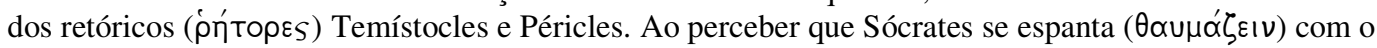
poder aparentemente divino ( $\delta \propto \iota \mu o v i ́ \alpha)$ ou sem fronteiras do orador, que persuade os outros sem conhecer aquilo acerca do que deveria persuadir, Górgias lhe diz, motivado pelo sentimento de vergonha, que a retórica deve ser realizada com justiça, embora não pareça preocupar-se verdadeiramente com os limites da habilidade discursiva que ensina, pois se exime de qualquer responsabilidade no caso de ela ser utilizada de modo injusto. ${ }^{57}$ Há, então, uma dissonância no conjunto de suas enunciações: se Górgias apresenta a retórica como uma arte axiologicamente neutra e, portanto, não determinada pelo conhecimento de uma đ̊ justo, ou seja, limitado?

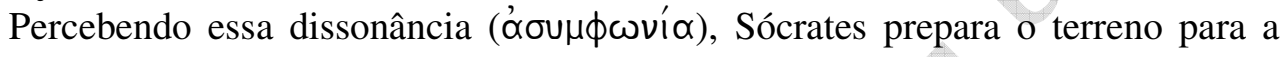
refutação de seu interlocutor. Ao discorrer a respeito do élenkhos, ele não só revela que tipo de homem é, mas também instiga Górgias a continuar a discussão e a enfrentar a refutação de modo vigoroso e destemido. Ele pergunta e responde a si mesmo:

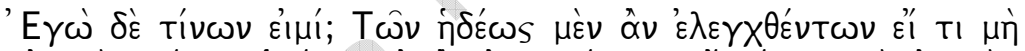

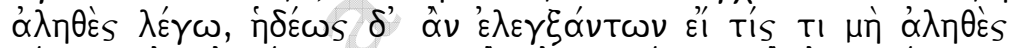

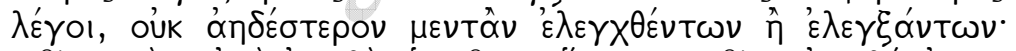

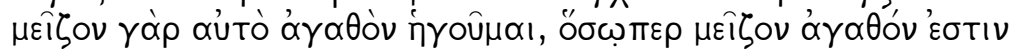

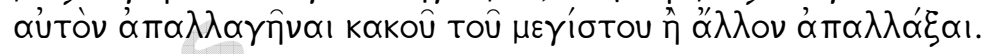

Que tipo de homem eu sou? Daqueles que seriam prazerosamente

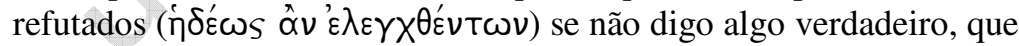
prazerosamente refutariam ( $\left.\dot{\eta} \delta \varepsilon^{\prime} \omega S \hat{\alpha} \nu{ }^{\prime} \varepsilon \lambda \varepsilon \gamma \xi \alpha^{\prime} \nu \tau \omega \nu\right)$ alguém que não dissesse algo verdadeiro e que certamente não seriam refutados com

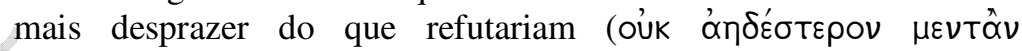

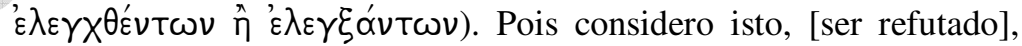
um bem maior, na medida em que é um bem maior alguém ser libertado do maior mal do que libertar outrem. ${ }^{58}$

Sócrates tem prazer não só em refutar, mas, sobretudo, em ser refutado, pois

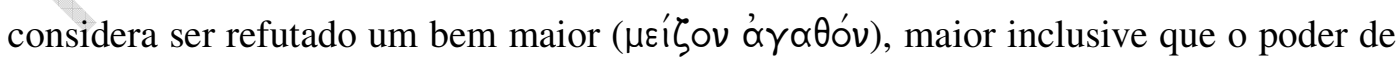

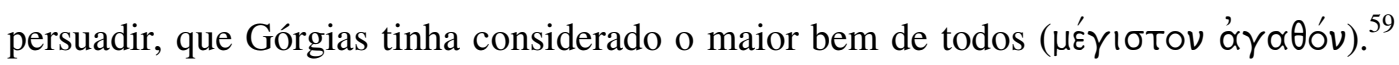

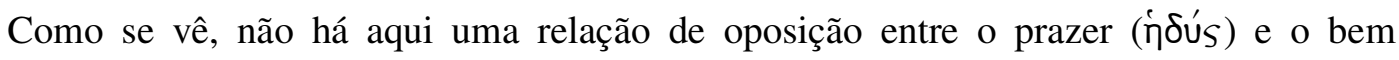
('̛̊ $\propto \theta$ ós), mas de subordinação. Platão se refere nesse trecho a um prazer regulado pelo

\footnotetext{
${ }^{57}$ Cf. Górgias $457 \mathrm{~b}-\mathrm{c}$.

58 Cf. Górgias 458a2-7.

${ }^{59}$ Cf. Górgias $452 \mathrm{~d} 5$.
} 
bem, compreendido por nós como a causa de inteligibilidade; ${ }^{60}$ é em função da mediação da inteligência que o interlocutor reconhece o proveito do élenkhos e se predispõe a submeter-se a ele com prazer. A refutação tem para a alma um proveito análogo ao que a medicina tem para o corpo, enquanto esta pode libertar o corpo das doenças, aquela pode libertar a alma de um de seus grandes males, sua crença de saber o que não sabe. A analogia entre o lógos terapêutico e a medicina, que é aludida no Górgias, é explicitada no Sofista: enquanto a medicina pretende remover os obstáculos internos do corpo, a fim de que ele tire maior proveito dos alimentos que ingere, a refutação pretende purificar a alma, ou seja, libertá-la de suas crenças ou opiniões falsas, a fim de que, pensando saber apenas o que sabe, ela seja capaz de conhecer algo; ${ }^{61}$ essa também é a grande finalidade do élenkhos no Górgias. Orientando-se pela inteligência, os homens conseguem ver o valor e o proveito dessas terapias e a se submeterem a elas com prazer, ainda que, de imediato, só consigam ver o que elas têm de doloroso.

Embora diga ser um homem desse tipo, que considera a refutação algo bom e aprazível, Górgias tenta escapar dela como quem foge de um grande mal; é por vergonha (a’ıxpós) dos ouvintes, mais do que pela mediação da inteligência, que ele resolve continuar a discussão. Ao ser indagado sobre o poder da retórica, Górgias diz

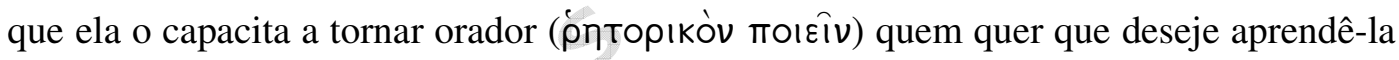
e que o orador, ao contrário dos outros artesãos, não precisa conhecer as próprias coisas para persuadir a multidão, basta, para isso, que ele disponha de um mecanismo de

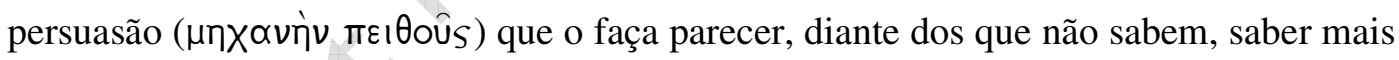

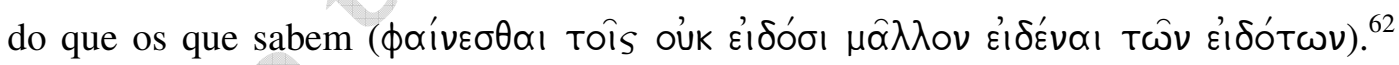
Porém, de modo precipitado e em desarmonia ${ }^{63}$ com o que havia dito antes, ele admite

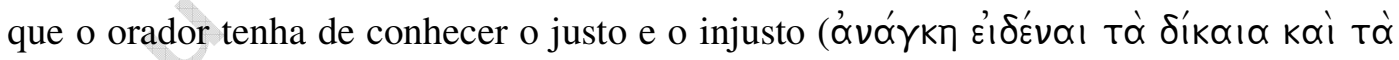

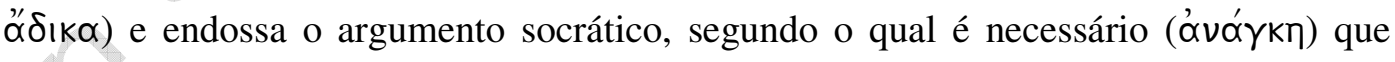

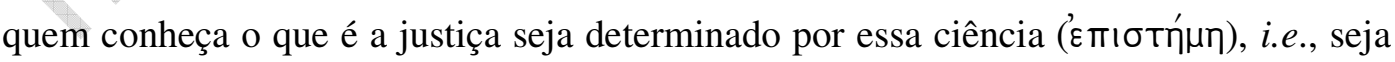

\footnotetext{
${ }^{60}$ Ainda que o bem não tenha no Górgias o sentido que passa a ter na República 506c-509d, a analogia textual que Platão estabelece neste diálogo entre a luz do sol, causa da "visibilidade empírica", e o bem, causa da "visibilidade da alma", isto é, da "inteligibilidade", ajuda-nos a compreender um pouco o seu sentido no Górgias.

${ }^{61}$ Cf. Sofista $230 \mathrm{c}-\mathrm{d}$.

${ }^{62}$ Cf. Górgias 459c.

${ }^{63}$ Platão faz repetidas referências à amusía de Górgias, que, por dizer ora uma coisa, ora outra, acaba

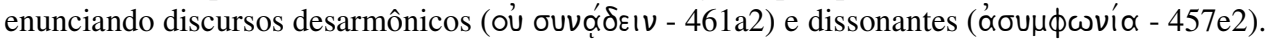




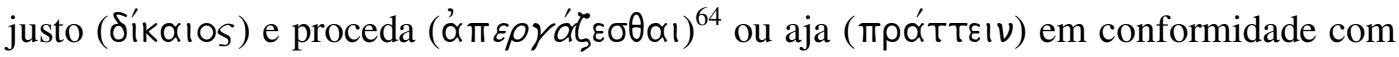
essa determinação. ${ }^{65}$ Ao concordar com essa tese, Górgias entra em desacordo consigo mesmo, pois havia admitido, em 457b, a possibilidade de o retórico fazer um uso ilimitado, ou seja, não justo de sua suposta arte.

Concluímos, então, que definir o que é uma TÉ X $\chi \eta$ não é apenas estabelecer o que ela é conceitualmente, mas, sobretudo, o limite de seu poder e realização. Górgias não consegue definir a retórica apontando o objeto de seu conhecimento porque recusa sua determinação; porque pretende que sua ocupação seja soberana com relação às outras TÉXv@ı, usurpando a imagem do conhecimento delas e subjugando-as. É devido ao desejo hybrístico de persuadir e agradar a todos a partir do uso irrestrito que faz dos discursos e das imagens, que ele cai em contradição ('Evavtíos) consigo mesmo: Górgias pensa que o poder que a retórica tem de agir pelo discurso não deve ser restringido pelas determinações do conhecimento, mas acaba assentindo ( conveniência de ocasião, que o orador tem de conhecer a justiça e ser determinado por esse conhecimento, procedendo ou agindo em conformidade com ele. Sócrates, então, não só refuta seu discurso, como também contesta sua pretensão de erigir a retórica ao estatuto de uma TÉXVฤ; ele denuncia, com ironia, a arbitrariedade do ofício do orador, que, tentando escapar de toda e qualquer determinação, acaba se tornando escravo das circunstâncias, em razão das quais não cansa de dizer ora uma coisa, ora outra.

Antes de encerramos este artigo, ressaltamos que, embora Sócrates diga mais de uma vez que não refuta Górgias, mas seu discurso (dimensão lógica do élenkhos), o que ele pretende é fazer com que seu interlocutor, provando uma dificuldade consigo próprio (dimensão psicológica), liberte-se de suas contradições e se disponha verdadeiramente a conhecer algo (dimensão epistemológica), vindo a discorrer e a agir

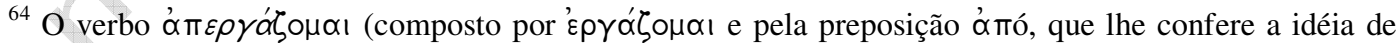
realização e acabamento) tem um sentido que não é totalmente estranho ao do termo XEıрoupría

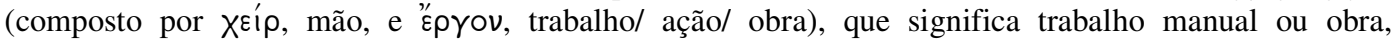
empregado por Górgias de modo a revelar o preconceito grego com relação às atividades manuais, consideradas escravas ou não livres (450b-c). Sócrates, filho do artesão Sofronisco, subverte os valores gregos ao enxergar na desprestigiada prática profissional de seu pai um aspecto filosófico; volta e meia ele estabelece uma analogia entre o conhecimento técnico do artesão, que na Apologia 22c é chamado de

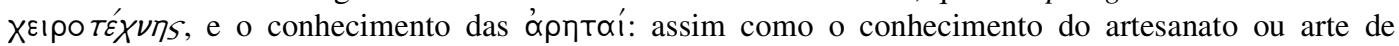
produzir artefatos deve determinar não só sua realização, mas também aquilo que um homem é enquanto realizador desse conhecimento (i.e., artesão), o conhecimento da justiça deve determinar não só sua realização, mas também aquilo que um homem é enquanto realizador desse conhecimento (i.e., justo). Vale dizer que um homem é determinado ou definido pelo conhecimento de certa arte ou excelência; ele é o que é na medida em que realiza as determinações desse conhecimento.

${ }^{65}$ Cf. Górgias 460b.
} 
em conformidade com as determinações desse novo conhecimento (conseqüência

política). ${ }^{66}$ Apesar de não dizer se Sócrates é bem sucedido ou não em seu propósito, a partir e para além da trama dialógica do Górgias, Platão, entre outras coisas, mostra ao leitor que ser refutado quando se diz algo contraditório e não verdadeiro, ao invés de um grande mal, é um bem maior.

\section{Referências}

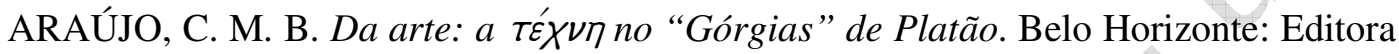
UFMG, 2008.

BRANDÃO, J. L.; SARAIVA, M. O. de Q.; LAGE, C. F. Helleniká. Introdução ao grego antigo. Belo Horizonte: Editora UFMG, 2005.

BRANDWOOD, Leonard A. A word index to Plato. Leeds: W. S. Maney \& Son, 1976.

CAMBIANO, G. Remarques sur Platon et la technè. Revue philosophique de la France et de l'étranger. Paris, vol. 4, p. 407-416, 1991.

CASERTANO, G. Palavra, verdade e engano em Górgias de Leontinos. Cadernos de Filosofia. Lisboa, vol. 9-10, p. 113-132, 2001.

CHANTRAINE, P. Dictionnaire étymologique de la langue grecque. Paris: Klincksieck, 1977.

CRESPO, E.; CONTI, L., MAQUIEIRA, H. Sintaxis del griego clásico. Madrid: Gredos, 2003.

DENNISTON, J. D. The Greek particles. Oxford: University Press, 1959.

DIELS, H; KRANZ, W. Die Fragmente der Vorsokratiker. Grieschish und Deutsch, 6. Aufl. Berlin: (1901) 1951-1952.

DIXSAUT, M. Le naturel philosophe. Essai sur les dialogues de Platon. Paris: Les Belles Lettres, 1994.

\footnotetext{
${ }^{66}$ Platão, com menos didatismo, articula o tempo todo as dimensões lógica, psicológica, epistemológica e política do élenkhos.
} 
2001.

. Métamorphoses de la dialetique dans les dialogues de Platon. Paris: Vrin,

. Réfutation et dialectique. In: DILlON, J.; DIXSAUT, M. (org.). Agonistes. Essays in Honour of Denis O’brien. London: Ashgate Publishing, 2005, p. 943.

DORION, Louis-André. La subversion de l'élenchos juridique dans 1'“Apologie de Socrate". Revue philosophique de Louvain. Louvain, vol. 88, p. 311-344, 1990.

DUMONT, J.-P. Les écoles présocratiques. Paris: Gallimard, 1991.

GÓRGIAS. Tratado do não-ente. Elogio de Helena. Tradução de M. Cecília Coelho. Cadernos de Tradução - USP. São Paulo, n. 4, p. 5-19, 1999.

HANSEN, M. H. The Athenian "Politicians", 403-322 B.C. Greek, Roman and Byzantine Studies. Duke, vol. 24, n. 1, p. 33-55, 1983.

HOMERO. Ilíada/ Odisséia. Tradução de Carlos Alberto Nunes. Rio de Janeiro: Ediouro, 2001/ 2002.

HUMBERT, J. Syntaxe grecque. Paris: Librairie C. Klincksieck, 1945.

KAHN, C. H. Did Plato write socratic dialogues? Classical Quarterly. Oxford, vol. 31, p. 305-320, 1981.

. Drama and dialectic in Plato's "Gorgias". Oxford studies in ancient philosophy. Oxford, vol. 1, p. 75-121, 1983.

KERFERD, G. B. The sophistic movement. Cambridge: University Press, 1981.

1981.

. O movimento sofista. Tradução de Margarida Oliva. São Paulo: Loyola,

LIDDELL, Henry; SCOTT, Robert; JONES, Stuart. A Greek-English lexicon. Oxford: Clarendon Press, 1996.

MALHADAS, D.; DEZOTTI, M. C. C.; NEVES, M. H. de M. Dicionário gregoportuguês. Cotia: Ateliê Editorial, 2006. Vol I, II e III [๔-o].

MARQUES, M. P. O Sofista: uma fabricação platônica? Kritérion. Belo Horizonte, vol. 102, p. 66-88, 2002. 


\section{nuntius antiquus}

UFMG, 2006.

Platão, pensador da diferença. Uma leitura do "Sofista". Belo Horizonte: 7, p.11-45, 2007.

Os sofistas: o saber em questão. Filósofos na sala de aula. São Paulo, vol.

MUNIZ, Fernando. Dialética socrática entre a ironia e a parrhesia. Boletim do CPA. Campinas, vol. 13/ 14, p. 97-108, 2002.

. Dialética e incomensurabilidade no "Górgias" de Platão. Boletim do CPA.

Campinas, vol. 15, p. 35-42, 2003.

PLATON. Apologie de Socrate. Criton. Traduction par Luc Brisson. Paris: GFFlammarion, 1997.

. Gorgias. E. R. Dodds (org.). Oxford: Claredon Press, 1959.

. Gorgias. Traduction par M. Canto-Sperber. Paris: GF-Flammarion, 1989.

. Lachès. Eithyphron. Traduction par L.-A. Dorion. Paris: GF-Flammarion, 1997.

. Láques. Tradução de Francisco de Oliveira. Lisboa: Edições 70, 1989.

. Le banquet. Traduction par Brisson. Paris: GF-Flammarion, 2005.

. Ménon. Traduction par M. Canto-Sperber. Paris: GF-Flammarion, 1991.

Loyola, 2001.

. Mênon. Tradução de M. Iglésias. Rio de Janeiro/ São Paulo: PUC-Rio/

. Euvres Complètes. Traduction et organisation par L. Robin. Paris: Gallimard, 1959-1960.

. Cuvres Complètes. Paris: Les Belles Lettres, 1920-1956.

. Phèdre. Traduction par Luc Brisson. Paris: GF-Flammarion, 1989.

Platonis Opera. Burnet, J. (org.). Oxford: Clarendon Press, 1900-1907. 


\section{nuntius antiquus}

. Sophiste. Traduction par N.-L. Cordero. Paris: GF-Flammarion, 1993.

. Théétète. Traduction par M. Narcy. Paris: GF-Flammarion, 1994.

. The Republic of Plato. James Adam (org.). Cambridge: University Press, 1980.

République. Traduction par Georges Leroux. Paris: GF-Flammarion 2002.

QUESNEL, A. A Grécia. Mitos e lendas. Tradução de Ana Maria Machado. São Paulo: Ática, 1996.

SCOTT, G. A. (org.). Does Socrates have a method? Rethinking the elenchus in Plato's dialogues and beyond. Pennsylvania: Penn State Press, 2002.

TUCÍDIDES. História da guerra do Peloponeso. Tradução de Mário da Gama Kury. Brasília: UNB, 1999.

de SOUZA, José Cavalcante. A caracterização dos sofistas nos primeiros diálogos platônicos. São Paulo. Boletim - USP: Língua e Literatura Grega. São Paulo, vol. 8, p. 109-155, 1969.

VLASTOS, G. The socratic elenchus. Oxford studies in ancient philosophy. Oxford, vol. 1, p. 27-58, 1983.

The Socratic elenchus: method is all. In: Socratic studies. Cambridge: University Press, 1994.

Socrates, ironist and moral philosopher. Cambridge: University Press, 1991. 